\title{
PENERAPAN MATRIKS STRATEGIS SISTEM INFORMASI: Studi Kasus di Dinas Perpustakaan Umum dan Arsip Daerah (DPAD) Kota Malang
}

\author{
Zahrotul Mufidah, \\ e-mail: zahrotulmufidah20@gmail.com
}

Program Studi S1 Ilmu Perpustakaan - Universitas Negeri Malang

\begin{abstract}
Abstrak: Dalam artikel ini akan dibahas empat kelompok sistem informasi tersebut yang tertuang dalam matriks strategis sistem informasi Warren McFarlan dan akan dikaitkan dengan perpustakaan khususnya dalam bidang layanan. DPAD Kota Malang telah menerapkan teknologi dan sistem informasi di beberapa kegiatan perpustakaan khususnya di bidang layanan. Metode penelitian ini mengguna metode studi kasus. Dari studi analisis menggunakan strategic matrix Warren McFarlan, diperoleh hasil bahwa posisi sistem informasi di DPAD Kota Malang dalam kategori kelompok pertama 'support', yaitu sistem informasi kepegawaian; kelompok kedua 'factory', yaitu sistem informasi data anggota; kelompok ketiga 'turnaround', yaitu sistem web chat; dan kelompok keempat 'strategic', yaitu sistem OPAC.
\end{abstract}

Kata kunci: teknologi, sistem informasi, strategic matrix.

Abstract: In this article will discuss the four groups of the information system set out in the strategic matrix Warren McFarlan and information systems will be associated with the library, especially in the field of services. DPAD Malang has implemented technology and information systems in some library activities particularly in the field of services. This research method use you the case study method. From the study of strategic analysis using matrix Warren McFarlan, the result that the position of information systems in the DPAD Malang in the first group category 'support', ie personnel information system; The second group 'factory', ie the member data information systems; The third group 'turnaround', ie web chat system; and fourth groups 'strategic', the OPAC system.

Keywords: technology, information systems, strategic matrix

\section{PENDAHULUAN}

Teknologi informasi pada saat ini telah berkembang dengan pesat. Perkembangan tersebut diiringi dengan penggunaan yang meningkat di berbagai sektor kehidupan dan menciptakan adanya arus perubahan. Hal ini menyebabkan teknologi informasi memiliki kedudukan atau peran yang penting baik bagi 
perseorangan, masyarakat, maupun organisasi. Oleh karena itu, diperlukan sebuah sistem yang dapat mengontrol setiap perkembangan dan perubahan agar teknologi informasi dapat didayagunakan dengan baik. Sistem tersebut biasa disebut dengan sistem informasi.

Bagi sebuah perusahaan yang sudah menerapkan teknologi informasi khususnya untuk mendukung kegiatan perusahaan, sistem informasi sangat diperlukan. Hal ini disebabkan oleh adanya persaingan bisnis antar perusahaan yang dapat menentukan keberhasilan maupun kegagalan perusahaan dalam menjalankan misinya (bisnis). Sebuah perusahaan harus dapat menentukan strategi yang baik dalam memanajemen sistem informasi.

Salah satu strategi sistem informasi yang dapat digunakan adalah matriks startegis sistem informasi yang dirancang oleh Warren McFarlan. Matriks ini menggambarkan peranan sebuah sistem informasi di perusahaan atau organisasi. Peran tersebut dilihat dari dua perspektif, yaitu (1) seberapa besar ketergantungan sebuah perusahaan atau organisasi terhadap keberadaan teknologi informasi dalam penciptaan produk atau jasa sehari-harinya dan (2)

seberapa besar perkembangan teknologi informasi dapat menciptakan atau meningkatkan keunggulan kompetitif.

Dalam matriks strategis sistem informasi Warren McFarlan, sistem informasi dikategorikan menjadi empat kelompok, yaitu kelompok pertama, kedua, ketiga, dan keempat. Kelompok pertama dinamakan support, keelompok kedua dinamakan factory, kelompok ketiga dinamakan turnaround, dan kelompok keempat dinamakan strategic. Kelompok-kelompok tersebut menunjukkan tingkatan sistem informasi dari tingkatan yang terendah hingga tingkatan yang tertinggi.

Matriks strategis informasi tersebut juga dapat di terapkan di perpustakaan untuk memudahkan petugas perpustakaan dalam mengelola perpustakaan. Dengan adanya sistem informasi, pengguna perpustakaan juga akan memperoleh kemudahaan dalam mengakses informasi dan dapat memanfaatkan layanan perpustakaan. Sistem informasi yang diterapkan dapat dijadikan sebuah keunggulan dalam bersaing dengan perpustakaan lain.

Dalam artikel ini akan dibahas empat kelompok sistem informasi tersebut 
yang tertuang dalam matriks strategis sistem informasi Warren McFarlan dan akan dikaitkan dengan perpustakaan khususnya dalam bidang layanan. Contoh studi kasus yang diambil adalah peneraoan sistem informasi oleh Dinas Perpustakaan Umum dan Arsip Daerah (DPAD) Kota Malang, karena DPAD Kota Malang telah menerapkan sistem informasi di perpustakaan dalam skala besar sehingga diperlukan sebuah acuan untuk melihat atau menilai sebuah sistem informasi yang sudah berjalan.

\section{Sistem Informasi}

Sistem informasi merupakan suatu sistem yang terdiri atas sekumpulan komponen berbasis komputer dan manual. Menurut Jogiyanto HM (2009:36-37), tujuan dari sistem informasi adalah menghasilkan informasi. Informasi tersebut harus didukung oleh tiga pilar, yaitu (1) tepat kepada orangnya atau relevan (relevance); (2) tepat waktu (timeliness); dan (3) tepat nilainya atau akurat (accurate). Apabila informasi tidak didukung oleh tiga pilar tersebut, maka informasi tidak dapat dikatakan sebagai informasi yang berguna atau hanya menjadi sampah (garbage.

Selain itu, menurut Khristanto, Totok, \& Sri (2015:6), secara teknis sistem informasi digunakan untuk mengumpulkan, memproses, menyimpan, dan mendistribusikan informasi untuk mendukung pengambilan keputusan dan kendali dalam suatu organisasi. Sistem informasi juga dapat membantu suatu organisasi untuk meneliti suatu permasalahan dan menciptakan produk baru.

Sistem informasi memiliki peranan penting dalam sebuah organisasi. Menurut Alter (dalam Kadir, 2003:8), terdapat empat peranan penting sistem informasi dalam organisasi yaitu (1) berpartisipasi dalam pelaksanaan tugas-tugas; (2) mengaitkan perencanaan, pengerjaan, dan pengendalian dalam sebuah subsistem; (3) mengordinasikan subsistem-subsistem; dan (4) mengintegrasikan subsistem-subsistem. Subsistem-subsistem tersebut merupakan ruang lingkup sistem informasi yang terdiri dari organisasi, teknologi, dan manajemen. Untuk lebih jelasnya dapat dilihat pada gambar berikut (Lihat Gambar 1). 


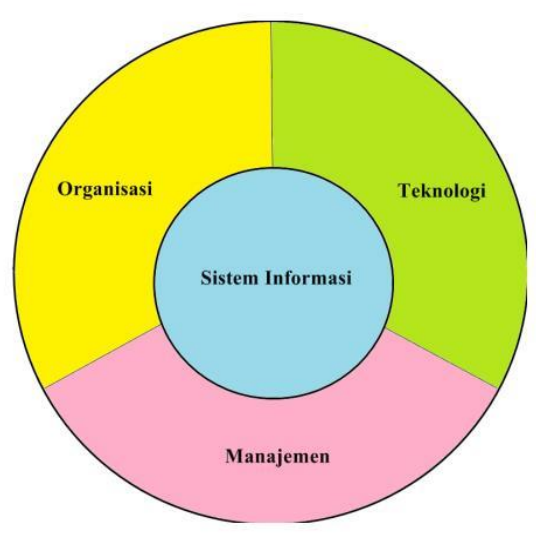

\section{Gambar 1. Ruang Lingkup Sistem Informasi}

Sumber: Buku Ajar Sistem Informasi Manajamen (Pendekatan Sosioteknik) oleh Wheny Khristianto, Totok Supriyanto, dan Sri Wahyuni.

Berdasarkan Gambar 1 dapat dijelaskan bahwa antarsubsistem saling mendukung terciptanya dan berjalannya sistem informasi dalam sebuah organisasi. Ketika sistem informasi tersebut diterapkan dalam sebuah organisasi maka diperlukan perangkat teknologi, karena teknologi merupakan perangkat komponen sistem informasi. Kemudian, untuk mengatur, menjalankan, dan mengendalikan sistem informasi diperlukan suatu manajemen termasuk di dalamnya sumber daya manusia (manajer, pegawai, karyawan, dkk,). Menurut Pebrianto (2010:44), subsistem sistem informasi harus saling berinteraksi untuk mencapai tujuan bersama.

Sistem informasi memungkinkan perusahaan untuk meningkatkan pendapatan atau mengurangi biaya dengan memberikan informasi yang membantu manager membuat keputusan yang lebih baik dan tepat serta meningkatkan kinerja perusahaan. Namun, dalam sebuah perusahaan tidak semua sistem informasi yang ada memiliki peranan yang sama, karena tingkat kepentingan masing-masing perusahaan berbeda. Penting bagi seorang manajemen puncak untuk mengetahui betul dan mendefiniskan secara jelas peranan masing-masing sistem informasi. Hal ini dilakukan untuk mencegah terjadinya kelebihan investasi yang dapat membengkakkan biaya overheat perusahaan atau kekurangan investasi yang dapat mengakibatkan kehilangan kesempatan (opportunity lost). 


\section{Penerapan Sistem Informasi di Perpustakaan}

Perpustakaan merupakan salah satu sumber informasi yang dapat dimanfaatkan oleh masyarakat pengguna untuk memenuhi kebuhan informasi. Menurut Suwarno (2011:13), perpustakaan adalah suatu unit kerja yang di dalamnya terdapat organisasi. Dalam arti, kegiatan perpustakaan melibatkan lebih dari satu individu untuk saling berkerjasama mencapai tujuan.

Pada era digital dan informasi saat ini, perpustakaan bukan lagi tempat penyimpanan buku, melainkan tempat penghimpunan, penyimpanan, pengeloaan, pelayanan, dan penyebarluasan hingga pengevaluasian informasi. Selain itu, menurut Sutarno NS (2006:15), perpustakaan telah menjadi tempat penemuan, penelitian, dan pengetahuan yang menyediakan informasi dari berbagai sumber7. Namun, informasi tidak hanya terbatas pada koleksi tercetak, melainkan juga koleksi digital seperti artikel/e-jurnal yang dipublikasikan di web perpustakaan.

Perubahan paradigma perpustakaan dari konvensional menuju digital dan virtual membuat perpustakaan menerapkan teknologi informasi di perpustakaan. Penerapan ini tidak lepas dari upaya perpustakaan untuk memberikan pelayanan yang terbaik bagi masyarakat pengguna. Masyarakat pengguna menghendaki perpustakaan menjadi right information, right user dan right now (Pebrianto, 2010:43)8. Dalam arti, perpustakaan dituntut untuk memberikan layanan informasi yang tepat, pada pengguna yang tepat, dan waktu yang cepat. Hal ini dapat terlaksana dengan baik apabila perpustakaan dapat menghadirkan dan memanfaatkan perkembangan teknologi informasi dalam pengelolaan perpustakaan.

Dengan demikian, perpustakaan memerlukan sebuah sistem informasi agar teknologi informasi yang diterapkan dapat berjalan baik dan sesuai dengan yang diharapkan. Sistem tersebut dapat meliputi sistem database koleksi, penelusuran informasi, website, user account, administratif, kepegawaian, dan lain-lain. Sistem informasi di perpustakaan juuga perlu dikembangkan secara terus menerus agar menjadi perpustakaan yang unggul dan dapat bersaing dengan perpustakaan lain.

\section{Matriks Strategis Sistem Informasi Warren McFarlan}

Salah satu kerangka matriks Warren McFarlan yang masih relevan untuk 
digunakan sebagai bahan analisis sistem informasi dalam sebuah organisasi seperti perusahaan dan perpustakaan adalah Strategic Matrix. Secara prinsip, peranan sebuah sistem informasi dari satu perusahaan ke perusahaan lainnya berbeda. Hal ini disebabkan oleh posisi sistem informasi di suatu organisasi dilihat dari dua perspektif utama, yaitu (1) seberapa besar ketergantungan perusahaan terhadap sistem informasi dan teknologi informasi; dan (2) seberapa besar potensi sistem informasi dan teknologi untuk dapat memberikan keuntungan kompetitif bagi perusahaan.

Dalam Strategic Matrix terdapat empat kategori kelompok sistem informasi, di antaranya: (1) support; (2) factory; (3) turnaround; dan (4) strategic. Kategori kelompok tersebut menunjukkan posisi sistem informasi di sebuah organisasi. Indrajit menjelaskan bahwa sebuah perusahaan harus dapat memetakan setiap aplikasi atau infrastruktur teknologi informasi yang dimilikinya ke dalam matriks yang ada sehingga manajemen dapat melihat tingkat kepentingan masing-masing sistem informasi yang dimiliki untuk keperluan perencanaan dan pengembangannya. Untuk lebih jelasnya dapat dilihat pada gambar berikut (Lihat Gambar 2).

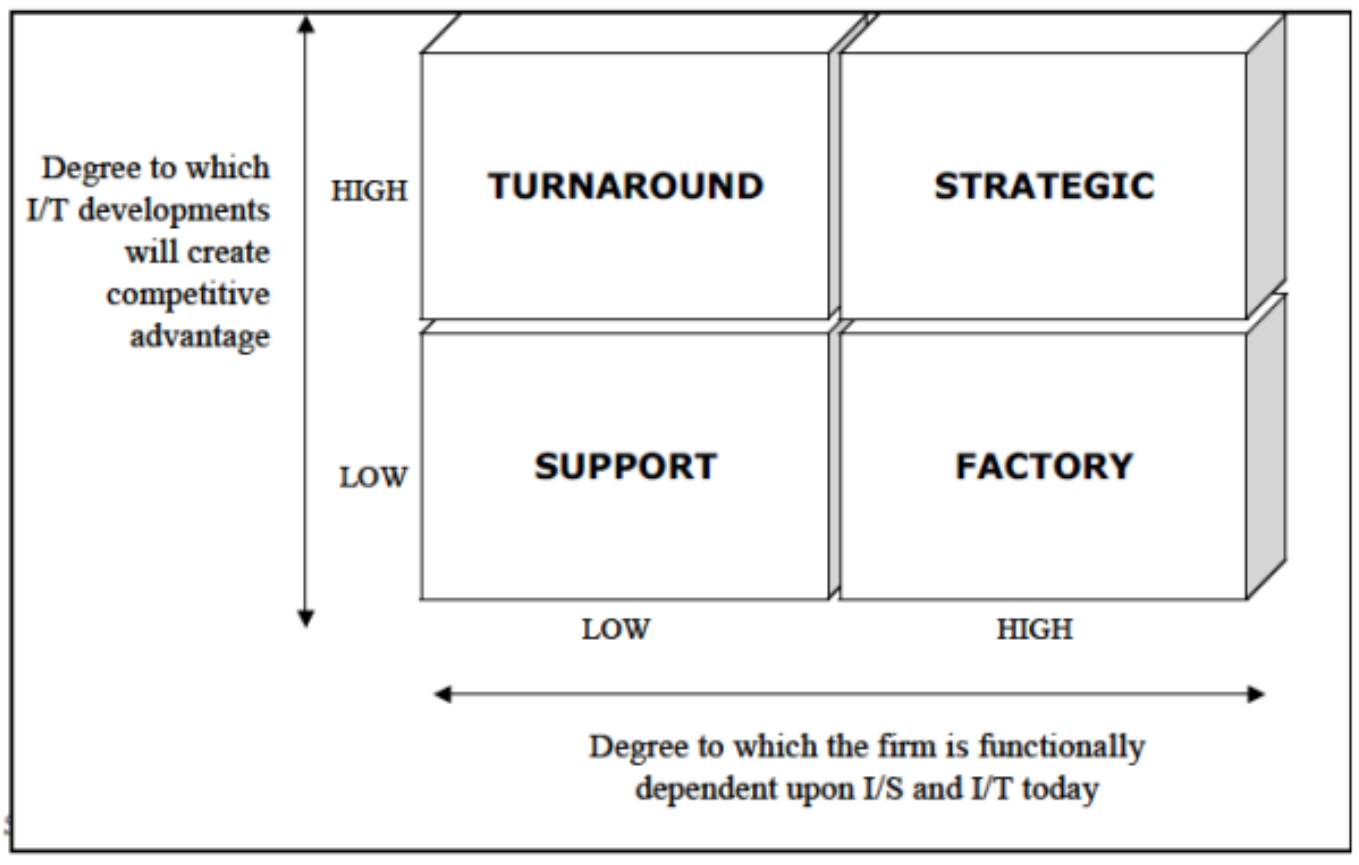

Gambar 2. Information System Stategic Matrix Warren McFarlan 


\section{Sumber: Kumpulan Artikel Richardus Eko Indrajit}

Kelompok pertama (support), yaitu sistem informasi atau teknologi informasi yang hanya berfungsi sebagai penunjang perusahaan (kinerja perusahaan tidak bergantung kepada peranan teknologi informasi) dan tidak memiliki potensi yang besar dalam memberikan keunggulan kompetitif perusahaan9. Sebagai contoh, sistem penggajian karyawan di perusahaan surat kabar. Kinerja perusahaan tidak bergantung pada kecanggihan teknologi yang digunakan, karena yang dijadikan patokan adalah kualitas informasi dalam surat kabar yang dihasilkan. Sistem yang bersangkutan juga tidak membedakan keunggulan perusahaan dibandingkan dengan perusahaan sejenis lainnya.

Kelompok kedua (factory), yaitu teknologi informasi yang tidak secara langsung memberikan keunggulan kompetitif kepada perusahaan, namun keberadaannya mutlak diperlukan10. Sebagai contoh, sistem informasi customer pada sebuah bank mengingat bahwa data lengkap customer harus dimiliki oleh sebuah bank, karena segala perhitungan (seperti premi dan klaim) sangat bergantung kepada profil perorangan. Namun, sistem ini tidak secara khusus memberikan keunggulan kompetitif bagi pihak bank dengan bank lainnya (pesaing).

Kelompok ketiga (turnaround), yaitu sistem informasi yang secara langsung dapat memberikan keunggulan kompetitif kepada perusahaan yang memilikinya, namun secara prinsip perusahaan tersebut tidak bergantung eksistensinya terhadap sistem informasi yang bersangkutan11. Sebagai contoh, aplikasi sistem telemedicine pada industri rumah sakit. Tanpa adanya sistem ini, rumah sakit dapat berjalan seperti biasanya tanpa ada gangguan yang berarti. Namun, dengan adanya Sistem Telemedicine dapat menghubungkan rumah sakit yang bersangkutan dengan masyarakat melalui internet sehingga dapat meningkatkan daya saing rumah sakit tersebut dengan rumah sakit lainnya (Indrajit).

Kelompok keempat (stratetig), yaitu sistem informasi yang paling utama, karena secara signifikan memiliki nilai strategis bagi perusahaan dan tanpa sistem ini, perusahaan dapat gulung tikar. Sebagai contoh, fasilitas ATM bagi sebuah 
bank yang dapat memudahkan para calon pelanggan untuk melakukan transfer, pengambilan, cek saldo, dll. Dengan sistem ini pelanggan akan memilih bank yang menyediakan akses kemudahan baginya. Dalam arti, pelanggan memperoleh kepuasan layanan.

\section{Metode Analisis}

Metode yang digunakan dalam analisis mini riset ini adalah metode studi kasus dengan melakukan analisis dan evaluasi menggunakan studi literatur strategic matrix Warren McFarlan terkait dengan penggunaan sistem informasi pada sebuah organisasi. Menurut Mulyana (2010:201), studi kasus adalah uraian dan penjelasan secara komprehensif mengenai berbagai aspek seorang individu, kelompok, organisasi, program, ataupun situasi sosial. Dengan metode ini, diharapkan peneliti dapat memperoleh informasi yang mendalam tentang penerapan sistem informasi di DPAD Kota Malang dan menilai posisi sistem informasi tersebut menggunakan strategic matrix.

\section{PEMBAHASAN}

\section{Analisis Penerapan Sistem Informasi di DPAD Kota Malang Menggunakan} Strategic Matrix

DPAD Kota Malang telah menerapkan teknologi dan sistem informasi di perpustakaan di semua bidang kegiatan perpustakaan terutama di bidang layanan. Hal ini dilakukan untuk memberi kemudahan bagi petugas perpustakaan dalam mengelola perpustakaan dan bagi masyarakat pengguna dalam memanfaatkan layanan perpustakaan. Mengingat ruang lingkup kerja dan layanan DPAD cukup luas, karena merupakan perpustakaan umum daerah yang melayani pengguna dari semua lapisan masyarakat.

Penerapan teknologi dan sistem informasi di DPAD Kota Malang meliputi tersedianya sistem finger print untuk presensi pegawai perpustakaan, sistem kepegawaian (data pegawai, penggajian), sistem administratif perpustakaan, website, sistem penelusuran informasi (OPAC), sistem informasi data anggota, sistem presensi anggota perpustakaan dan peminjaman-pengembalian koleksi (Smart Library Automation), database koleksi, digital library, mobile library, 
web-chat, dan seperangkat komputer beraudio beserta kelengkapannya untuk pengguna difabel. Oleh karena itu, dslam artikel ini akan membahas mengenai beberapa posisi sistem informasi yang diterapkan oleh DPAD Kota Malang dan menganalisisnya menggunakan strategic matrix Warren McFarlan [(1) support; (2) factory; (3) turnaround; dan (4) strategic).

\section{Support}

Sistem informasi dalam kategori 'support', yaitu sistem informasi yang hanya berfungsi sebagai penunjang perusahaan (kinerja perusahaan tidak bergantung kepada peranan teknologi informasi) dan tidak memiliki potensi yang besar dalam memberikan keunggulan kompetitif perusahaan. Sistem informasi ini dalam strategic matrix Warren McFarlan dikategorikan sebagai kelompok pertama. Sebagai studi kasus di DPAD Kota Malang, sistem informasi dalam kategori ini adalah sistem informasi kepegawaian.

Sistem informasi kepegawaian DPAD Kota Malang digunakan untuk pengolahan dan penyimpanan data pegawai termasuk di dalamnya sistem penggajian dan presensi pegawai. Sistem ini hanya berfungsi sebagai penunjang kegiatan di perpustakaan dan tidak menjadi nilai lebih atau keunggulan bagi perpustakaan dengan perpustakaan lainnya. Hal ini disebabkan oleh karena indikasi keberhasilan sebuah perpustakaan bukanlah pada canggihnya teknologi yang diterapkan, melainkan produk (jasa) informasi yang dihasilkan dan dilayankan. Hal tersebut dapat dinilai demikian apabila dilihat dari sudut pandang strategic matrix kelompok pertama 'support'.

\section{Factory}

Sistem informasi dalam kategori 'factory', yaitu teknologi informasi yang tidak secara langsung memberikan keunggulan kompetitif kepada perusahaan, namun keberadaannya

mutlak diperlukan. Sistem informasi ini dalam strategic matrix Warren McFarlan dikategorikan sebagai kelompok kedua. Sebagai studi kasus di DPAD Kota Malang, sistem informasi dalam kategori ini adalah sistem informasi data anggota.

Sistem informasi data anggota DPAD Kota Malang digunakan untuk pengolahan dan penyimpanan data anggota perpustakaan. Sistem ini memang 
tidak secara langsung menjadi nilai lebih atau keunggulan bagi DPAD, namun penerapan sistem ini sangat diperlukan. Dalam arti, data lengkap anggota perpustakaan harus dimiliki oleh sebuah perpustakaan, karena hal tersebut berhubungan dengan segala perhitungan (seperti premi dan klaim) yang sangat bergantung kepada profil anggota.

Dengan adanya sistem informasi data anggota ini juga akan mempermudah dalam penelusuran informasi data anggota dibandingkan dengan sistem pencatatan manual. Namun, sistem ini tidak secara khusus memberikan keunggulan kompetitif bagi pihak DPAD Kota Malang dengan perpustakaan lainnya, karena di setiap perpustakaan khususnya yang sudah menerapkan sistem teknologi informasi pasti memiliki data anggota. Hal tersebut dapat dinilai demikian apabila dilihat dari sudut pandang strategic matrix kelompok kedua 'factory'.

\section{Turnaround}

Sistem informasi dalam kategori 'turnaround', yaitu sistem informasi yang secara langsung dapat memberikan keunggulan kompetitif kepada perusahaan yang memilikinya, namun secara prinsip perusahaan tersebut tidak bergantung eksistensinya terhadap sistem informasi yang bersangkutan. Sistem informasi ini dalam strategic matrix Warrren McFarlan dikategorikan sebagai kelompok ketiga. Sebagai studi kasus di DPAD Kota Malang, sistem informasi dalam kategori ini adalah sistem informasi atau fasilitas web chat.

Sistem informasi atau fasilitas web chat DPAD Kota Malang digunakan sebagai media komunikasi antara pengguna perpustakaan dengan pustakawan. Tanpa adanya sistem ini, DPAD Kota Malang dapat berjalan seperti biasanya yang berarti. Namun, dengan adanya web chat dapat menghubungkan DPAD dengan masyarakat pemgguna melalui jaringan internet. Hal ini dapat meningkatkan daya saing DPAD dengan perpustakaan lainnya. Masyarakat pengguna akan dapat berdialog dengan mudah melalui fasilitas chatting tersebut dengan seorang pihak DPAD atau pustakwan, seperti sharing atau menanyakan adanya gangguan akses layanan perpustakaan ataupun hanya sekedar menanyakan jam buka perpustakaan, dll. Pertanyaan atau sharing dari pengguna akan direspon 
langsung oleh pustakawan DPAD.

Sistem ini akan menjadikan nilai lebih atau keunggulan bagi pihak DPAD Kota Malang, karena sejauh ini belum banyak perpustakaan yang memiliki sistem tersebut. Selain itu, dengan adanya sistem ini juga dapat memungkinkan terciptanya kepuasan pengguna dalam

hal layanan. Hal tersebut dapat dinilai demikian apabila dilihat dari sudut pandang strategic matrix kelompok ketiga 'turnaround'.

\section{Strategic}

Sistem dalam kategori 'strategic', yaitu sistem informasi yang paling utama, karena secara signifikan memiliki nilai strategis bagi perusahaan dan tanpa sistem ini, perusahaan dapat gulung tikar. Sistem informasi ini dalam strategic matrix Warrren McFarlan dikategorikan sebagai kelompok keempat. Sebagai studi kasus di DPAD Kota Malang, sistem informasi dalam kategori ini adalah sistem penelusuran informasi melalui online public access catalogue (OPAC).

Sistem ini digunakan DPAD Kota Malang untuk kegiatan penelusuran informasi maupun koleksi perpustakaan. Sistem ini memberi kemudahan bagi pengguna perpustakaan untuk menelusur informasi atau koleksi perpustakaan secara online. Fasilitas OPAC tersedia di website perpustakaan (perpustakaan.malangkota.go.id). Dengan adanya sistem ini pengguna tidak harus datang ke perpustakaan hanya untuk melihat tersedia tidaknya informasi atau koleksi yang dibutuhkan. Selain itu, bagi pengguna yang datang ke perpustakaan dan hendak menelusur informasi khususnya koleksi, sistem ini akan mempermudah penelusuran koleksi di rak, karena informasi koleksi tersebut tercantum dalam sistem OPAC. Pengguna akan merasa senang apabila kemudahan akses layanan diperoleh. Pada dasarnya, pengguna mengingkan hal yang simple, mudah, dan tidak ribet.

Apabila DPAD Kota Malang tidak menerapkan sistem OPAC sebagai sarana penelusuran informasi, pengunjung maupun pengguna akan komplain karena kesulitan akses layanan dan bukan tidak mungkin perpustakaan akan sepi pengunjung. Apabila perpustakaan sepi pengunjung dan bahkan tidak ada pengunjung, maka perpustakaan tersebut tidaklah berarti, karena tidak ada yang 
memanfaatkan. Hal ini disebabkan oleh karena salah satu komponen penentu kemajuan dan keberhasilan sebuah perpustakaan adalah pada kegiatan layanan yang diberikan kepada masyarakat pengguna.

\section{KESIMPULAN}

DPAD Kota Malang telah menerapkan teknologi dan sistem informasi di perpustakaan. Hal ini dilakukan dalam hal peningkatan layanan kepada masyarakat pengguna. Posisi sistem informasi DPAD Kota Malang dapat dilihat menggunakan matriks strategis arren McFarlan. Berdasarkan analisis menggunakan matriks tersebut diperoleh kesimpulan sebagai berikut.

1. Sistem informasi kepegawaian berada dalam kategori kelompok pertama 'support'.

2. Sistem informasi data anggota berada dalam kategori kelompok kedua 'factory'.

3. Sistem informasi/fasilitas web-chat berada dalam kategori kelompok ketiga 'turnaround'.

4. Sistem penelusuran informasi melalui OPAC berada dalam kategori kelompok keempat 'strategic'.

\section{DAFTAR RUJUKAN}

Indrajit, Richardus Eko. 2012. Skala Prioritas Sistem Informasi. (Online), (https://www.academia.edu/14337525/Skala_Prioritas_Sistem_Informasi), diakses pada 5 Maret 2017.

Indrajit, Richardus Eko. Konsep Dasar: Manajemen Sistem Informasi dan Teknologi Informasi. (Online), ( http://repository.unand.ac.id/18152/1/Manajemen\%20Sistem\%20Informasi. pdf ), diakses pada 5 Maret 2017.

Jogiyanto HM. 2009. Sistem Teknologi Informasi. Yogyakarta: ANDI.

Kadir, Abdul. 2003. Pengenalan Sistem Informasi. Yogyakarta: ANDI.

Khristianto, Wheny, Supriyanto, Totok, \& Wahyuni, Sri. 2015. Buku Ajar Sistem Informasi Manajamen (Pendekatan Sosioteknik). (Online), ( http://repository.unej.ac.id/bitstream/handle/123456789/73674/Wheny\%20 K,\%20Totok\%20S,\%20Sri\%20W_Buku\%20Informasi\%20Manajemen_(FI 
SIP).pdf?sequence=1 ), diakses pada 5 Maret 2017.

Mulyana, Deddy. 2010. Metode Penelitian Kualitatif. Jakarta:Rosda.

Pebrianto, Slamet. Pembangunan Sistem Informasi Perpustakaan Pada Perpustakaan Umum Kabupaten Pacitan, (Online), http://ijns.org/journal, diakses 31 Maret 2017.

Sidharta, Iwan. Manajemen Sistem Informasi. (Online), ( http://iwansidharta.com/downlot.php?file=MSI5.pdf ), diakses pada 5 Maret 2017.

Sutarno NS. 2006. Perpustakaan dan Masyarakat. Jakarta: Sagung Seto.

Suwarno, Wiji. 2011. Perpustakaan dan Buku: Wacana Penulisan \& Penerbitan. Yogjakarta: Ar-Ruzz Media. 